\title{
Campylobacter showae sp. nov., Isolated from the Human Oral Cavity
}

\author{
YUMIKO ETOH, ${ }^{1 *}$ FLOYD E. DEWHIRST, ${ }^{2}$ BRUCE J. PASTER, ${ }^{2}$ \\ AYAKO YAMAMOTO ${ }^{1}$ AND NOBUICHI GOTO ${ }^{1}$ \\ Department of Oral Microbiology, Showa University School of Dentistry, 1-5-8 Hatanodai, Shinagawa-ku, \\ Tokyo 142, Japan, ${ }^{1}$ and Forsyth Dental Center, Boston, Massachusetts $02115^{2}$
}

\begin{abstract}
Nine Campylobacter-like strains were isolated from human gingival crevices and characterized. These strains were gram-negative, straight rods that were motile by means of multiple unipolar flagella. They were asaccharolytic and preferred an anaerobic atmosphere rather than a microaerophilic atmosphere for growth, and their growth was stimulated by formate and fumarate. These strains were biochemically similar to Campylobacter curvus and Campylobacter rectus, but were clearly distinguishable from these organisms by the number of flagella (two to five flagella at one end of the cell), by being catalase positive, by their whole-cell protein profiles, by their Western blot (immunoblot) patterns, and on the basis of DNA-DNA homology data. They could also be differentiated from the other species of the genus Campylobacter. The nine Campylobacterlike strains were compared with two strains (FDC 286 and VPI 10279) representing a previously described but unnamed Wolinella sp. The nine isolates and strains FDC 286 and VPI 10279 were found to be members of a single species. The 16S rRNA sequences of two strains of the newly identified species were compared with the rRNA sequences of 21 reference Campylobacter, Wolinella, and Helicobacter species in order to generate a phylogenetic tree. We propose the name Campylobacter showae for the newly identified strains; strain SU A4 (= ATCC 51146) is the type strain of this new species.
\end{abstract}

Previously, we isolated several Wolinella-like strains from human subgingival dental plaque (16) and subsequently proposed Wolinella curva subsp. intermedius as a new subspecies for two of the isolates ( $\mathrm{SU} \mathrm{A4} 4^{\mathrm{T}}$ [ $\mathrm{T}=$ type strain] and SU A5) (4). These organisms could be differentiated at least at the subspecies level by morphological, biochemical, antigenic, and DNA-DNA homology methods from the other human oral Wolinella species, $W$. curva and Wolinella recta, which recently have been transferred to the genus Campylobacter as Campylobacter curvus and Campylobacter rectus, respectively, by Vandamme et al. $(24,25)$. In order to more fully describe the status of a new species in the genus Campylobacter, seven additional strains were isolated; thus, a total of nine strains, including SU $A 4^{\mathrm{T}}$ and $\mathrm{SU} \mathrm{A} 5$, were characterized. These nine isolates were compared with Wolinella sp. strains FDC 286 (22) and VPI 10279 (14) and strains of other Campylobacter species $(19,20,24,25)$. A 16S rRNA sequence analysis was used to determine the phylogenetic position of strains SU A4 ${ }^{\mathrm{T}}$ and VPI 10279. The nine isolates and strains FDC 286 and VPI 10279 are members of a new species, for which we propose the name Campylobacter showae.

\section{MATERIALS AND METHODS}

Bacterial strains and characterization. The sources and accession numbers of the isolates and reference strains examined in this study are shown in Table 1. The nine Campylobacter-like strains were isolated from the dental plaque of gingival crevices of nine apparently healthy adults on plates containing modified CBRCA (26), which is a selective medium for Campylobacter, Fusobacterium, Bacteroides, Selenomonas, and Veillonella strains and contains reinforced clostridial agar (Oxoid Ltd., Hampshire,

\footnotetext{
* Corresponding author.
}

England), 5\% horse blood, $0.03 \%$ China blue, $0.2 \%$ sodium formate, $0.3 \%$ sodium fumarate, and $0.5 \mu \mathrm{g}$ of menadion per $\mathrm{ml}$. The strains were maintained on brain heart infusion agar (Difco Laboratories, Detroit, Mich.) supplemented with 5\% horse blood, $0.2 \%$ sodium formate, and $0.3 \%$ sodium fumarate (basal medium) and were incubated at $37^{\circ} \mathrm{C}$ anaerobically in an $80 \% \mathrm{~N}_{2}-10 \% \mathrm{CO}_{2}-10 \% \mathrm{H}_{2}$ atmosphere. Growth under microaerophilic conditions, which were provided by a hydrogen and carbon dioxide generator envelope (GasPak Anaerobic System; BBL Microbiology Systems, Cockeysville, Md.), was tested in a GasPak jar without a catalyst on blood agar plates supplemented with $0.2 \%$ sodium formate and $0.3 \%$ sodium fumarate. Cell morphology was determined by transmission electron microscopy by using either platinum-carbon shadowing, negative staining, or ultrathin sections of the bacterial cells $(7,16)$. Catalase activity was tested by dropping a $3 \%$ hydrogen peroxide solution directly on bacteria grown on a plate containing brucella agar (Difco). Oxidase activity was determined with cytochrome oxidase test strips (Nissui Pharmaceutical Co., Ltd., Tokyo, Japan). Indoxyl acetate hydrolysis was determined by the impregnated disc method (5). Arylsulfatase activity was determined by hydrolysis of indoxyl sulfate in an indicator medium (27). Urease activity was determined by using Christensen (2) urease test agar (Remel, Lenexa, Kans.). Alkaline phosphatase and gamma-glutamyl transpeptidase activities were determined by hydrolysis of $0.1 \%$ solutions of $p$-nitrophenylphosphate or gamma-glutamyl-nitroanalide (Rapid NH System; Innovative Diagnostic Systems, Inc., Atlanta, Ga.). Reduction of nitrate and nitrite and production of hydrogen sulfide were determined by conventional methods (9). Lysine and ornithine decarboxylase activities were determined by using decarboxylase broth (Remel). Resistance to nalidixic acid and cephalothin was analyzed by using 50- and 30- $\mu \mathrm{g}$ discs (Showa Yakuhin Kako Co., Ltd., Tokyo, Japan), respectively. Growth in the presence of $0.01 \%$ Janus green, $0.005 \%$ basic fuchsin, $0.0005 \%$ crystal violet, $0.01 \%$ safranine, $0.025 \%$ methyl orange, $0.05 \%$ so- 
TABLE 1. Strains, sources, and accession numbers of sequences

\begin{tabular}{|c|c|c|c|}
\hline Strain or taxon & Source $^{a}$ & Culture collection ${ }^{b}$ & GenBank accession no. $^{c}$ \\
\hline \multicolumn{4}{|l|}{ Campylobacter-like strains } \\
\hline $\mathrm{SU} \mathrm{A} 4^{\mathrm{T} d}$ & Gingival crevice & $\operatorname{ATCC} 51146^{\mathrm{T}}\left(=\right.$ CCUG $\left.30254^{\mathrm{T}}\right)$ & L06974e \\
\hline $\mathrm{SU} \mathrm{A} 5^{d}$ & Gingival crevice & & \\
\hline $\mathrm{SU} \mathrm{A} 43^{d}$ & Gingival crevice & & \\
\hline SU A1221d & Gingival crevice & & \\
\hline SU B312 & Gingival crevice & & \\
\hline $\mathrm{SU} \mathrm{B} 329^{d}$ & Gingival crevice & & \\
\hline SU Ig $4^{d}$ & Gingival crevice & & \\
\hline SU Ig9 ${ }^{d}$ & Gingival crevice & & \\
\hline SU Ig $24^{d}$ & Gingival crevice & & \\
\hline Wolinella sp. strain FDC $286^{d}$ & Gingival crevice & & \\
\hline Wolinella sp. strain VPI $10279^{d}$ & Root canal & CCUG 11641 & $\mathrm{~L} 06975^{e}$ \\
\hline Campylobacter curvus & & ATCC $35224^{\mathrm{T}}$ & L04313 \\
\hline Campylobacter curvus & & SU C10 & $\mathrm{L} 06976^{e}$ \\
\hline Campylobacter concisus & & FDC $484^{\mathrm{T}}\left(=\operatorname{ATCC} 33237^{\mathrm{T}}\right)$ & L04322 \\
\hline Campylobacter concisus & & FDC 288 & $\mathrm{~L} 06977^{e}$ \\
\hline Campylobacter concisus & & FDC 569 & \\
\hline Campylobacter rectus & & ATCC $33238^{\mathrm{T}}$ & L04317 \\
\hline Campylobacter rectus & & CCUG 19168 & $\mathrm{~L} 06973^{e}$ \\
\hline Campylobacter sputorum biovar sputorum & & VPI S17 & \\
\hline Campylobacter sputorum biovar bubulus & & ATCC 33491 & L04319 \\
\hline Campylobacter fetus subsp. fetus & & ATCC $27374^{\mathrm{T}}$ & L04314 \\
\hline Campylobacter coli & & CCUG $11283^{\mathrm{T}}$ & L04312 \\
\hline Campylobacter hyointestinalis & & $\operatorname{ATCC} 35217^{\mathrm{T}}$ & M65010 \\
\hline Campylobacter jejuni subsp. jejuni & & CCUG $11284^{\mathrm{T}}$ & L04315 \\
\hline Campylobacter lari & & CCUG $23947^{\mathrm{T}}$ & L04316 \\
\hline Campylobacter mucosalis & & CCUG $6822^{\mathrm{T}}$ & $\mathrm{L} 06978^{e}$ \\
\hline Campylobacter species ${ }^{f}$ & & PGC $40-6 A T$ & L04318 \\
\hline Bacteroides gracilis & & ATCC $33236^{\mathrm{T}}$ & L04320 \\
\hline Bacteroides ureolyticus & & $\operatorname{ATCC} 33387^{\mathrm{T}}$ & L04321 \\
\hline Wolinella succinogenes & & ATCC $29543^{\mathrm{T}}$ & M88159 \\
\hline Helicobacter pylori & & ATCC $43504^{T}$ & M88157 \\
\hline Helicobacter felis & & ATCC $49179^{\mathrm{T}}$ & M37642 \\
\hline Helicobacter mustelae & & ATCC $43772^{\mathrm{T}}$ & M35048 \\
\hline Helicobacter muridarum & & ATCC $49282^{\mathrm{T}}$ & M80205 \\
\hline
\end{tabular}

${ }^{a}$ Source of isolate in a human oral cavity. The nine Campylobacter-like strains were isolated from the healthy adults at Showa University.

$b$ Culture collections in which strains have been deposited or from which strains were obtained. ATCC, American Type Culture Collection, Rockville, Md.; CCUG, Culture Collection, University of Göteborg, Göteborg, Sweden; FDC, Forsyth Dental Center, Boston, Mass.; PGC, Procter \& Gamble Co., Cincinnati, Ohio; SU, Showa University, Tokyo, Japan; VPI, Department of Anaerobic Microbiology, Virginia Polytechnic Institute and State University, Blacksburg.

$c$ The 16S rRNA sequences of some strains are available for electronic retrieval from GenBank under the accession numbers indicated. Through cross-distribution, these sequences should also be available from European (EMBL) and Japanese (DDBJ) data bases.

${ }^{d}$ Strain included in C. showae.

e Sequence determined in this study.

$f$ One of several genetically similar isolates from pigs which was used for 16S rRNA sequence analysis.

dium fluoride $(\mathrm{NaF}), 0.1 \%$ sodium deoxycholate, $1 \%$ oxgall, $1 \%$ glycine, and 2 and $3.5 \% \mathrm{NaCl}$ was tested by using methods described by Tanner et al. $(19,20)$. The guanineplus-cytosine $(\mathrm{G}+\mathrm{C})$ contents of DNAs were determined by reversed-phase high-performance liquid chromatography (HPLC) $(4,17)$.

SDS-PAGE. Bacterial cells were collected from basal medium agar plates and suspended in distilled water. After washing, the cells were resuspended and then lysed with $4 \%$ sodium dodecyl sulfate (SDS). The lysates were diluted with distilled water and mixed with equal volumes of sample buffer containing $0.125 \mathrm{M}$ Tris- $\mathrm{HCl}$ (pH 6.8), 4\% SDS, $20 \%$ glycerol, $10 \% 2$-mercaptoethanol, and $0.01 \%$ bromophenol blue (18). Samples of whole-cell proteins were loaded onto gels. Prestained SDS-polyacrylamide gel electrophoresis (PAGE) standards (type HMW; Bio-Rad Laboratories, Richmond, Calif.) were used as molecular weight markers. Discontinuous SDS-PAGE in a $10 \%$ separating gel and a $4 \%$ stacking gel (16 by $16 \mathrm{~cm}$; thickness, $0.75 \mathrm{~mm}$ ) was carried out with dual gels at $30 \mathrm{~mA}$ for 4 to $5 \mathrm{~h} \mathrm{(6).} \mathrm{After} \mathrm{electro-}$ phoresis, one of the gels was silver stained (21), and the other was soaked in a transfer buffer containing $0.1 \mathrm{M}$ Tris- $\mathrm{HCl}(\mathrm{pH} 7.5), 0.2 \mathrm{M}$ glycine, and $1 \%$ methanol for at least $30 \mathrm{~min}$ for subsequent electrotransfer.

Western blotting of SDS-PAGE gels. The soluble proteins from whole bacterial cells were transferred electrophoretically from each SDS-PAGE gel to a nitrocellulose membrane filter by using a Horiz-Blot apparatus (Atto Co., Tokyo, Japan) at $180 \mathrm{~mA}$ for $90 \mathrm{~min}$. The antisera used as the first antibodies for Western blotting (immunoblotting) were prepared by immunizing rabbits with intact live cells of strain SU A5, C. rectus ATCC $33238^{\mathrm{T}}$, or C. curvus ATCC $35224^{\mathrm{T}}$ as described by Badger and Tanner (1). Goat anti-rabbit immunoglobulin G-horseradish peroxidase conjugate (BioRad Laboratories) was used as the second antibody. The antigens on the filter bound to the antibodies were detected by using an Immuno-blot horseradish peroxidase assay system (Bio-Rad Laboratories) according to the manufacturer's instructions.

DNA isolation and purification. The DNAs were prepared as previously described (4). Briefly, bacterial cells were harvested and washed by centrifugation, suspended in sa- 
line-EDTA (0.15 M NaCl, 0.1 M EDTA; pH 8.0), and lysed by incubating them with SDS at a final concentration of $1.0 \%$ at $60^{\circ} \mathrm{C}$ for $10 \mathrm{~min}$. Then DNA was extracted with phenolchloroform-isoamyl alcohol $(25: 24: 1)$, precipitated with cold ethanol, and dissolved in Tris-EDTA buffer $(10 \mathrm{mM}$ Tris$\mathrm{HCl}[\mathrm{pH} 7.5], 1 \mathrm{mM}$ EDTA). The partially purified DNA was then digested with $\mathrm{RNase} A(0.5 \mathrm{mg} / \mathrm{ml})$ at $37^{\circ} \mathrm{C}$ for $30 \mathrm{~min}$ and with proteinase $\mathrm{K}(100 \mu \mathrm{g} / \mathrm{ml})$ at $37^{\circ} \mathrm{C}$ for $2 \mathrm{~h}$, and the enzyme was inactivated by shaking the preparation with an equal volume of chloroform-isoamyl alcohol (24:1). The DNA was precipitated with 2 volumes of ethanol and dissolved in Tris-EDTA buffer. The concentration and purity of DNA were determined by measuring $A_{234}, A_{260}$, and $A_{280}$.

DNA-DNA hybridization. The DNAs of strain SU A4 ${ }^{\mathrm{T}}, C$. rectus ATCC $33238^{\mathrm{T}}$, and C. curvus ATCC $35224^{\mathrm{T}}$ were labeled with [methyl $\left.-1^{\prime}, 2^{\prime}-{ }^{3} \mathrm{H}\right] \mathrm{d}$ TTP (tetrasodium salt; Du Pont, Inc., NEN Products, Boston, Mass.) by using a nick translation system (Du Pont, Inc.). The specific activities of the labeled DNAs were between $1.2 \times 10^{7}$ and $1.4 \times 10^{7}$ $\mathrm{cpm} / \mu \mathrm{g}$ of DNA. DNA-DNA hybridization experiments were carried out by using a membrane filter method $(10,23)$. Sheared and denatured DNAs were fixed on a nitrocellulose membrane filter $(9$ by $12 \mathrm{~cm}$ ) by aspirating preparations through wells of a microfiltration apparatus (Bio-Rad Laboratories). After air dying, the filter was baked at $80^{\circ} \mathrm{C}$ for $2 \mathrm{~h}$. The fixed DNAs were prehybridized at $42^{\circ} \mathrm{C}$ for 2 to $4 \mathrm{~h}$ in prehybridization buffer containing $50 \%$ formamide, $2 \times \mathrm{SSC}$ ( $1 \times \mathrm{SSC}$ is $0.15 \mathrm{M} \mathrm{NaCl}$ plus $0.015 \mathrm{M}$ sodium citrate), $5 \times$ Denhardt's solution, and $200 \mu \mathrm{g}$ of denatured salmon sperm DNA per $\mathrm{ml}$ and subsequently hybridized at $42^{\circ} \mathrm{C}$ overnight in a hybridization mixture $(50 \%$ formamide, $2 \times \mathrm{SSC}, 1 \times$ Denhardt's solution, $100 \mu \mathrm{g}$ of denatured salmon sperm DNA per $\mathrm{ml}$ ) containing $100 \mu \mathrm{l}$ of a ${ }^{3} \mathrm{H}$-labeled DNA solution. After hybridization, the filter was washed twice with $2 \times$ SSC, and a section of six wells corresponding to each strain was cut out. The filter section was dissolved in methylcellosolve, Aquasol-2 (Du Pont, Inc.) was added, and the radioactivity was measured with a liquid scintillation counter. Hybridization of salmon sperm DNA was used as a negative control with each DNA probe. The DNA-DNA hybridization experiments were repeated at least three times.

Isolation and purification of rRNA. rRNA was isolated from bacterial cells and partially purified by a modification of the procedure of Pace et al. (11), as previously described (12).

$16 S$ rRNA sequencing and data analysis. rRNA was sequenced by the modified Sanger dideoxy chain termination technique in which primers complementary to conserved regions were elongated with avian myeloblastosis virus reverse transcriptase (8). A program set for data entry, editing, sequence alignment, secondary structure comparison, similarity matrix generation, and phylogenetic tree construction for 16S rRNA data was written in Microsoft Quick BASIC for use on IBM PC-AT and compatible computers; rRNA sequences were entered and aligned as previously described (12). Similarity matrices were constructed by comparing only those base positions for which there were data for $90 \%$ of the sequences. Phylogenetic trees were constructed by the neighbor-joining method $(13,15)$.

GenBank accession numbers. The GenBank accession numbers for all strains examined in this study are shown in Table 1.

\section{RESULTS AND DISCUSSION}

Cell morphology and biochemical characteristics. A total of nine Campylobacter-like strains were isolated from human gingival crevices and examined. As determined by electron microscopy, the cells were straight rods approximately 0.5 to $0.8 \mu \mathrm{m}$ wide and 2 to $5 \mu \mathrm{m}$ long with round ends. Each cell had two to five unsheathed unipolar flagella that were 15 to $20 \mathrm{~nm}$ in diameter (Fig. 1A through D), whereas each $C$. curvus and $C$. rectus cell had only a single polar flagellum (data not shown). Although this feature is unique among the campylobacters, DNA-DNA homology and 16S rRNA sequencing data clearly place these organisms in the genus Campylobacter. Therefore, the definition of the genus Campylobacter should be emended to include species with single flagella and species with multiple flagella. In ultrathin sections (Fig. $1 E$ and F), the structure of the cell wall appeared to be typical of gram-negative rods, in which the cell wall is composed of an outer membrane, a periplasmic space, and an inner membrane. The cells were not covered with either a crystalline surface layer (3) or the hexagonal arrangement of macromolecular subunits (7) observed in $C$. rectus.

The following characteristics were shared by all nine Campylobacter-like strains (except where noted): colonies on blood agar plates supplemented with $0.2 \%$ sodium formate and $0.3 \%$ sodium fumarate were 1 to $2 \mathrm{~mm}$ in diameter, translucent, and convex; rapid darting motility occurred; the organisms did not form spores; the DNA G+C content was 44 to $46 \mathrm{~mol} \%$; growth occurred in anaerobic and microaerophilic atmospheres, but the organisms preferred anaerobic conditions; growth occurred at $42^{\circ} \mathrm{C}$ but not at $25^{\circ} \mathrm{C}$; growth was stimulated by the addition of formate and fumarate to the medium; growth occurred in the presence of sodium fluoride $(0.5 \mathrm{~g} /$ liter $)$, Janus green $(0.1 \mathrm{~g} /$ liter $)$, basic fuchsin (50 mg/liter), crystal violet (5 mg/liter) (eight of nine strains), safranine $(0.1 \mathrm{~g} /$ liter $)$, methyl orange $(0.25 \mathrm{~g} /$ liter $)$, glycine $(10$ $\mathrm{g} /$ liter) (six of nine strains), and oxgall $(10 \mathrm{~g} /$ liter) (six of nine strains); fumarate was reduced to succinate; the organisms were oxidase positive and urease negative; nitrate and nitrite were reduced; hydrogen sulfide was produced; the organisms were not able to oxidize or ferment carbohydrates; and the organisms were resistant to nalidixic acid. Strains SU $\mathrm{A} 4^{\mathrm{T}}$ and $\mathrm{SU}$ A5 were negative for alkaline phosphatase activity, hippurate hydrolysis, lysine and ornithine decarboxylase activities, and gamma-glutamyl transferase activity and positive for arylsulfatase activity and hydrolysis of indoxyl acetate. The major features distinguishing the Campylobacter-like strains from other species of genus Campylobacter are shown in Table 2.

SDS-PAGE. To distinguish phenotypically similar species, one-dimensional SDS-PAGE was carried out. The bacterial whole-cell proteins extracted from the nine Campylobacterlike strains, two strains of $C$. rectus, six strains of $C$. curvus, and Wolinella succinogenes were determined. The electrophoretic patterns, comprising 40 to 50 bands, were highly reproducible, and the intraspecies protein profiles for the Campylobacter-like strains, $C$. rectus, and $C$. curvus were similar (data not shown). The protein profiles of the nine Campylobacter-like strains were similar to each other (Fig. 2 , lanes 1 through 9) but were different from the profiles of the three reference strains, $C$. rectus ATCC $33238^{\mathrm{T}}, C$. curvus ATCC $35224^{\mathrm{T}}$, and $W$. succinogenes ATCC $29543^{\mathrm{T}}$ (Fig. 2, lanes 10 through 12), because of two characteristic bands in the profiles of the nine isolates (Fig. 2, lanes 1 through 9, two large arrows). C. rectus was characterized by 

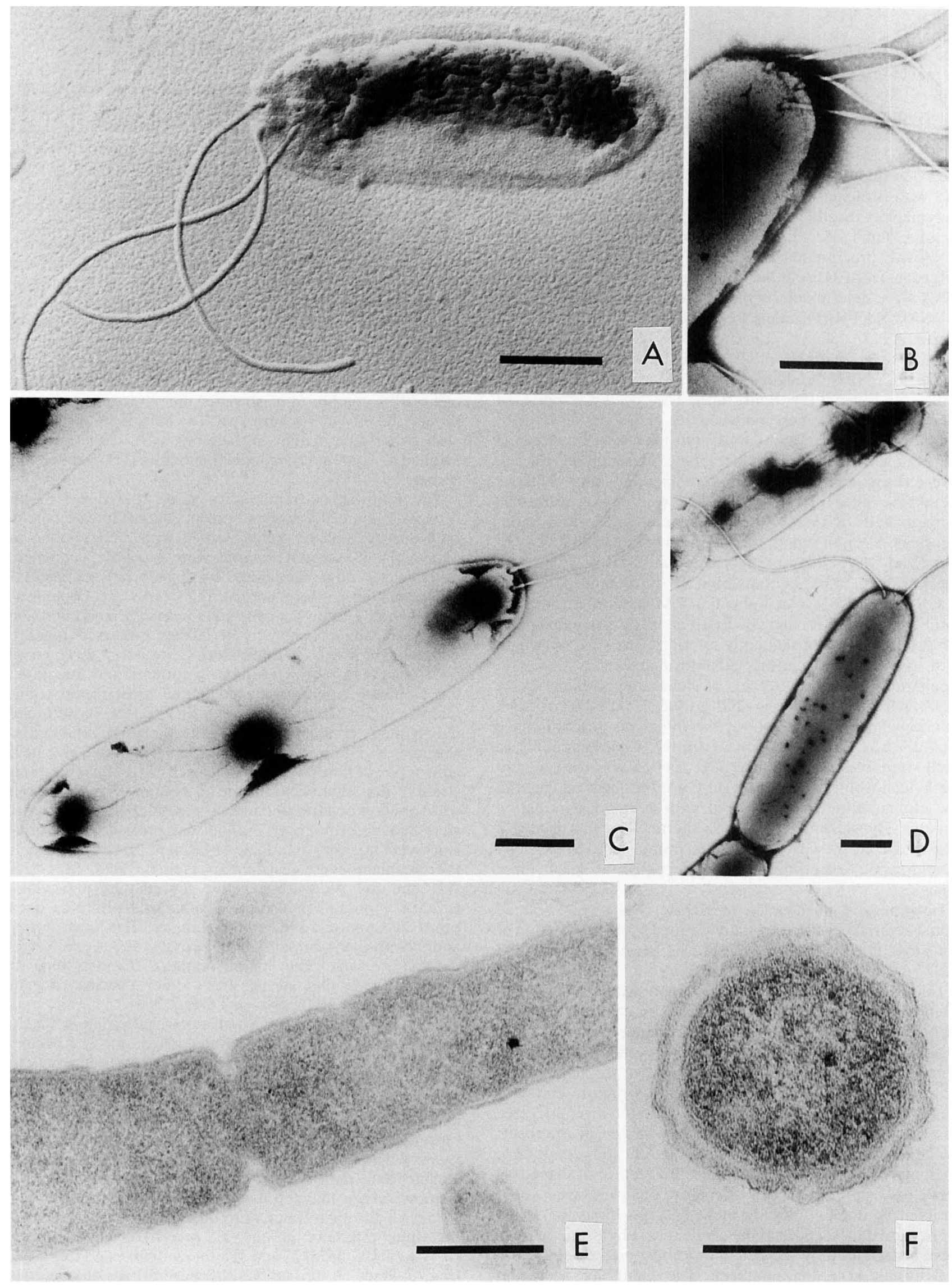

FIG. 1. Transmission electron micrographs of strain SU A5. (A) Platinum-carbon shadowing. (B through D) Negatively stained preparations. (E) Ultrathin section. (F) High-magnification micrograph of ultrathin section. Bars $=0.5 \mu \mathrm{m}$. 


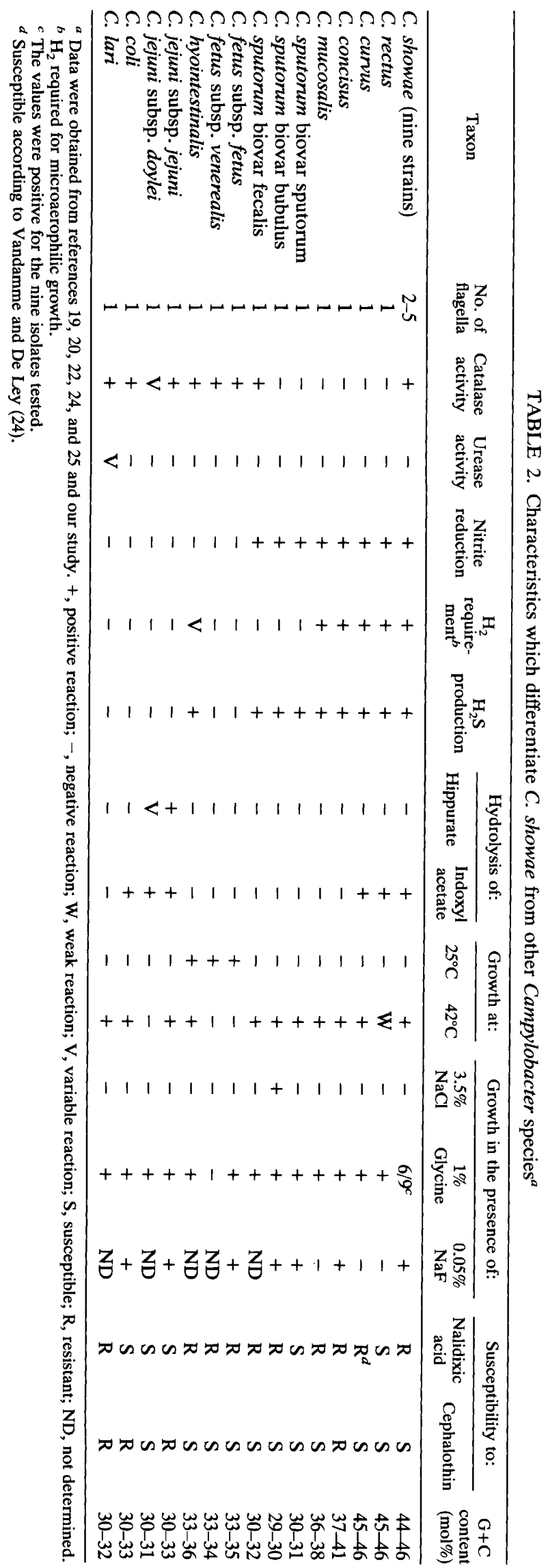

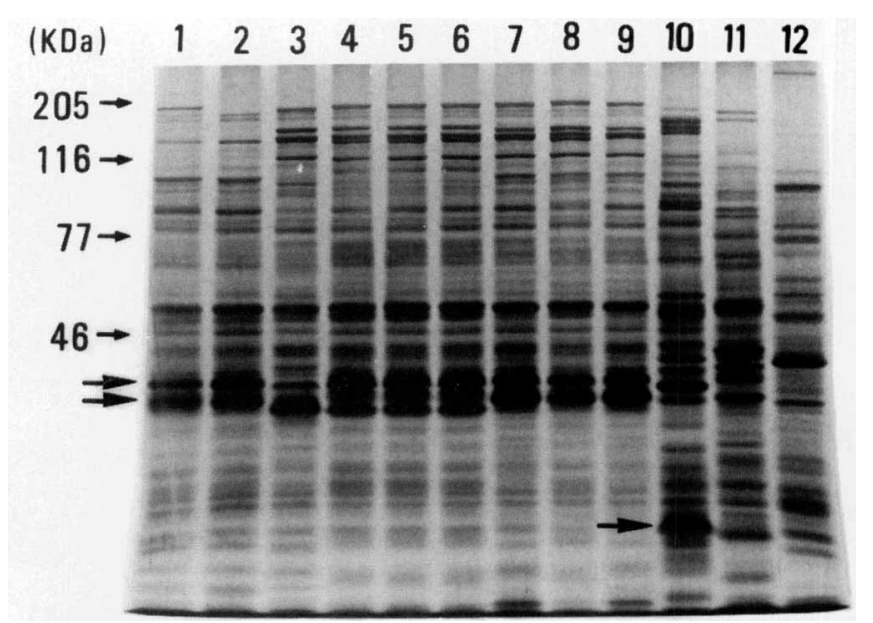

FIG. 2. Electrophoretic protein patterns of Campylobacter-like strains and the reference strains as determined by silver staining. Lanes 1 through 9, Campylobacter-like strains SU A4 ${ }^{\mathrm{T}}$ (lane 1), SU A5 (lane 2), SU A43 (lane 3), SU A1221 (lane 4), SU B312 (lane 5), SU B329 (lane 6), SU Ig4 (lane 7), SU Ig9 (lane 8), and SU Ig24 (lane 9); lane $10, C$. rectus ATCC $33238^{\mathrm{T}}$; lane $11, C$. curvus ATCC $35224^{\mathrm{T}}$; lane $12, W$. succinogenes ATCC $29543^{\mathrm{T}}$. The large arrow in lane 10 indicates the unique bands of $C$. rectus. The two large arrows on the left (lanes 1 through 9) indicate the characteristic bands of the Campylobacter-like strains.

a unique band (Fig. 2, lane 10, large arrow). To clearly differentiate the protein profiles, Western blotting was used.

Western blotting of SDS-PAGE gels. Whole-cell proteins from the nine Campylobacter-like strains and three reference strains separated by SDS-PAGE were transferred onto nitrocellulose membrane filters for Western blotting. The filters were incubated with antisera against strain SU A5 (Fig. 3A), C. rectus ATCC $33238^{\mathrm{T}}$ (Fig. 3B), and C. curvus ATCC $35224^{\mathrm{T}}$ (Fig. 3C). The Western blot patterns of the nine Campylobacter-like strains were relatively homogeneous. The principal protein bands between 116 and $205 \mathrm{kDa}$ appeared to be specific to the Campylobacter-like strains (Fig. 3A, lanes 1 through 9), whereas the bands in the middle indicated by the two large arrows were reactive with anti- $C$. rectus and anti-C. curvus sera, as well as anti-SU A5 serum (Fig. 3A through C). These cross-reactive bands, corresponding to the two major bands of Campylobacter-like strains determined by SDS-PAGE, appeared to be common antigens also present in $C$. rectus and $C$. curvus. The bands between 116 and $205 \mathrm{kDa}$ for $C$. rectus (Fig. 3B and C, lane 10, upper arrow) were cross-reactive with anti-C. rectus and anti-C. curvus sera, but not with anti-SU A5 serum. Lowmolecular-weight bands of $C$. rectus (Fig. 3B, lane 10, lower arrow) and $C$. curvus (Fig. 3C, lane 11, lower arrow) were specific to anti-C. rectus and anti-C. curvus sera, respectively. On the whole, the Western blot patterns of Campylobacter-like strains were characteristic and were distinct from the patterns of the phenotypically closely related organisms $C$. rectus and $C$. curvus.

DNA homology. The results of DNA-DNA hybridization experiments are shown in Table 3. The DNA homology data show that the nine Campylobacter-like strains and Wolinella sp. strains FDC 286 and VPI 10279 were closely related, with levels of DNA homology of more than $74 \%$, and formed a single group. On the other hand, the levels of DNA homology for this group ranged from 20 to $41 \%$ in comparisons with ${ }^{3} \mathrm{H}$-labeled DNA from $C$. rectus ATCC $33238^{\mathrm{T}}$ and were 


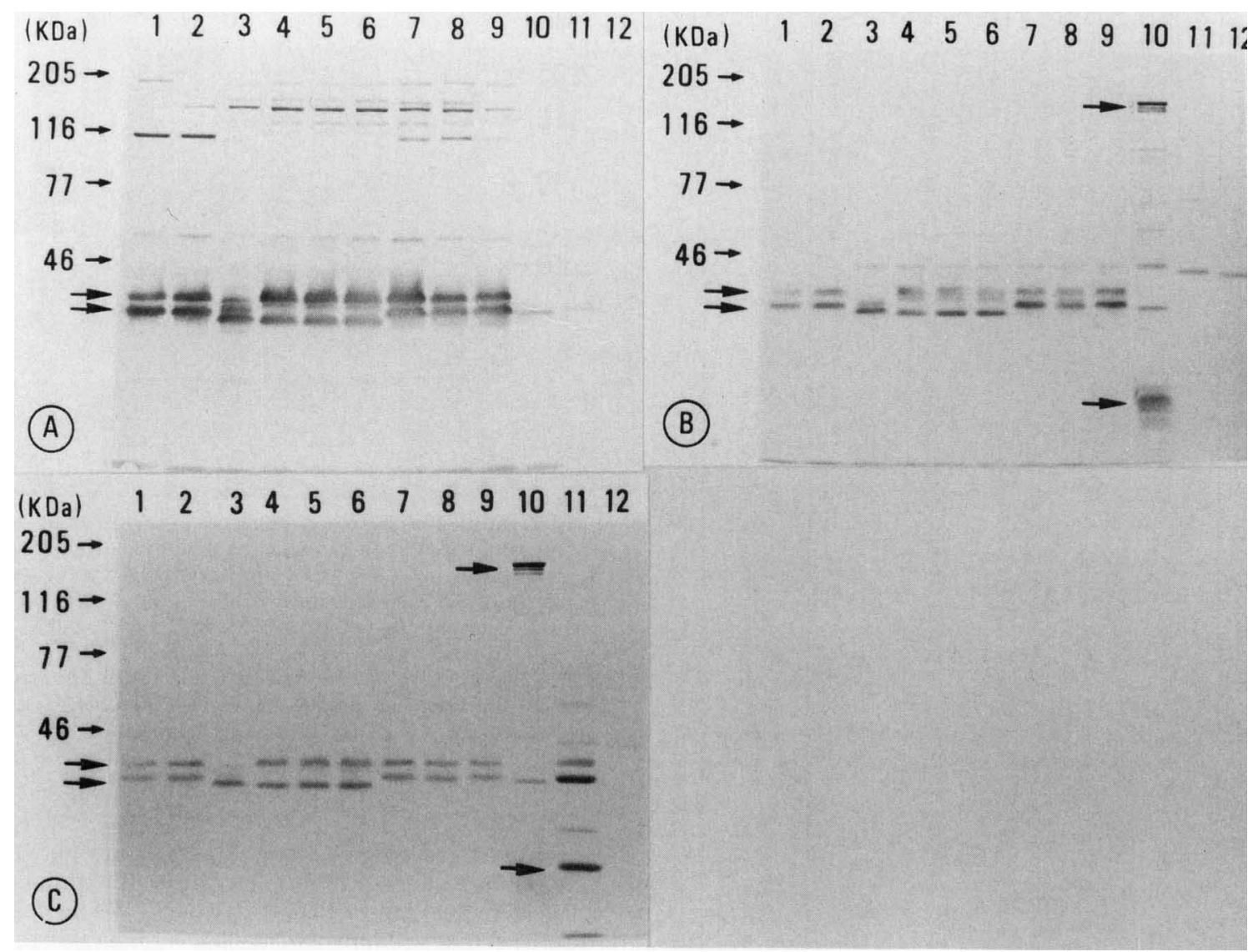

FIG. 3. Western blot patterns of the SDS-PAGE gel which is shown in Fig. 2. (A) Proteins incubated with anti-SU A5 serum. The two large arrows on the left indicate the common bands found in the nine Campylobacter-like strains. (B) Proteins incubated with anti-C. rectus serum. The two large arrows on the left indicate common bands found in the nine Campylobacter-like strains. In lane 10, the upper arrow indicates bands common to anti- $C$. rectus and anti-C. curvus sera, and the lower arrow indicates the bands specific to anti-C. rectus serum. (C) Proteins incubated with anti-C. curvus serum. The two large arrows on the left indicate common bands found in the nine Campylobacter-like strains. The large arrow in lane 10 indicates bands common to anti-C. rectus and anti-C. curvus sera, and the large arrow in lane 11 indicates the bands specific to anti-C. curvus serum.

less than $11 \%$ in comparisons with ${ }^{3} \mathrm{H}$-labeled DNA from $C$. curvus ATCC $35224^{\mathrm{T}}$. The levels of DNA homology between strain SU A4 ${ }^{\mathrm{T}}$ and Campylobacter concisus FDC 569 or $W$. succinogenes ATCC $29543^{\mathrm{T}}$ were much lower. Because of the high DNA-DNA homology values within this group (more than $74 \%$ ) and the low homology values with strains of other Campylobacter species (less than 41\%), the nine Campylobacter-like strains and Wolinella sp. strains FDC 286 and VPI 10279 should be regarded as belonging to a single new species. Our results are consistent with the previous findings of Tanner et al., who reported that strains FDC 286 and VPI 10279 represented an additional unnamed species in the genus Wolinella, which could be differentiated from $C$. curvus, $C$. rectus, and $W$. succinogenes by phenotypic characteristics and DNA-DNA homology data (22). The 16S rRNA sequence data compared with the 16S rRNA sequence data for other Campylobacter species strongly support placing this new species in the genus Campylobacter.

16S rRNA sequences. Essentially complete sequences (1,480 bases) were obtained for strains SU $A 4^{\mathrm{T}}$ and VPI 10279 and are available by electronic retrieval from GenBank under the accession numbers listed in Table 1. The 16S rRNA sequences of the following four additional Campylo-
TABLE 3. Levels of DNA-DNA homology among the nine Campylobacter-like strains, other Campylobacter strains, and related bacteria

\begin{tabular}{|c|c|c|c|}
\hline \multirow[b]{2}{*}{ Strain } & \multicolumn{3}{|c|}{$\begin{array}{c}\% \text { Homology with }{ }^{3} \mathrm{H} \text {-labeled } \\
\text { DNA from: }\end{array}$} \\
\hline & $\begin{array}{l}\text { Strain } \\
\text { SU A4 }\end{array}$ & $\begin{array}{l}\text { C. rectus } \\
\text { ATCC } \\
33238^{\mathrm{T}}\end{array}$ & $\begin{array}{l}\text { C. curvus } \\
\text { ATCC } \\
35224^{\mathrm{T}}\end{array}$ \\
\hline \multicolumn{4}{|l|}{ Campylobacter-like strains } \\
\hline SU A4 ${ }^{\mathrm{T}}$ & 100 & 20 & 5 \\
\hline SU A5 & 100 & 29 & 3 \\
\hline SU A43 & 82 & 34 & 7 \\
\hline SU A1221 & 74 & 32 & 7 \\
\hline SU B312 & 91 & 41 & 11 \\
\hline SU B329 & 90 & 36 & 10 \\
\hline SU Ig4 & 100 & 39 & 10 \\
\hline SU Ig9 & 82 & 33 & 8 \\
\hline SU Ig24 & 82 & 33 & 7 \\
\hline Wolinella sp. strain FDC 286 & 74 & 38 & 6 \\
\hline Wolinella sp. strain VPI 10279 & 80 & 36 & 5 \\
\hline C. rectus ATCC $33238^{\mathrm{T}}$ & 43 & 100 & 6 \\
\hline C. rectus CCUG 19168 & 49 & 73 & 3 \\
\hline C. curvus ATCC $35224^{\mathrm{T}}$ & 4 & 13 & 100 \\
\hline C. concisus FDC 569 & $<1$ & $<1$ & $<1$ \\
\hline W. succinogenes ATCC $29543^{\mathrm{T}}$ & $<1$ & $<1$ & $<1$ \\
\hline
\end{tabular}




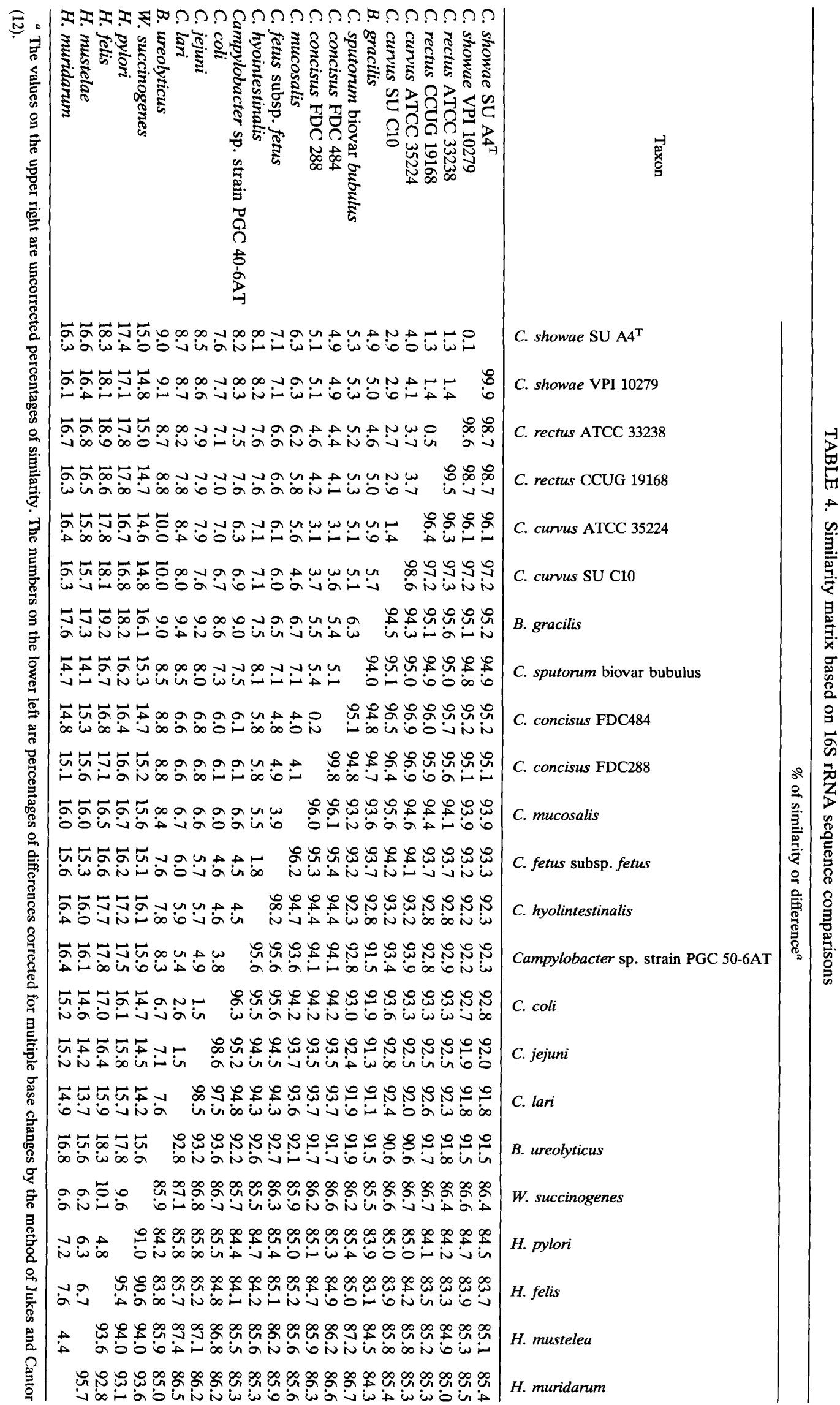


(\% Difference)

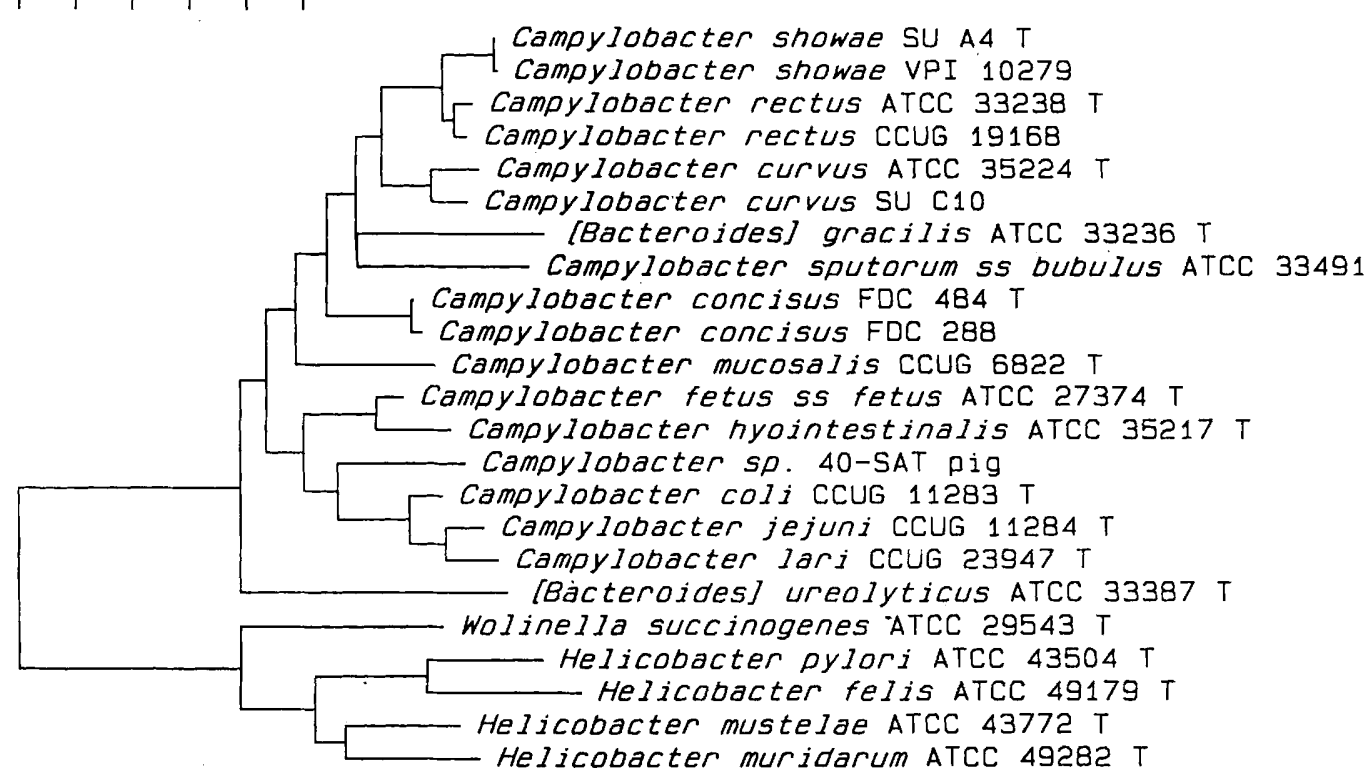

FIG. 4. Phylogenetic tree for 23 strains of Campylobacter, Helicobacter, and Wolinella species based on 16S rRNA sequence similarity data. The scale bar represents a 5\% difference in nucleotide sequences, as determined by measuring the lengths of the horizontal lines connecting any two species.

bacter strains have been deposited in the GenBank data base: $C$. curvus SU C10, C. concisus FDC 288, C. rectus CCUG 19168, and Campylobacter mucosalis CCUG $6822^{\mathrm{T}}$. The sequences of strains SU A4 ${ }^{\mathrm{T}}$ and VPI 10279 differed from one another by a single base and were $98.7 \%$ similar to the sequence of $C$. rectus.

Phylogenetic analysis based on 16S rRNA sequence comparisons. The 16S rRNA sequences of strains SU A4 ${ }^{\mathrm{T}}$ and VPI 10279 were aligned with the 16S rRNA sequences of 21 reference strains of Campylobacter, Helicobacter, and Wolinella species. A similarity matrix (Table 4) was determined by comparing the base positions for which $90 \%$ of the sequences had data and could be unambiguously aligned. The data matrix in Table 4 is based on comparisons at 1,400 base positions. A phylogenetic tree determined from this matrix by using the neighbor-joining method is shown in Fig. 4. As determined by $16 \mathrm{~S}$ rRNA sequence similarity, strains SU A4 ${ }^{\mathrm{T}}$ and VPI 10279 were most closely related to $C$. rectus; however, they differed from $C$. rectus at $1.35 \%$ of the positions, which was about the same level of difference observed between Campylobacter jejuni and Campylobacter coli or between $C$. jejuni and Campylobacter lari. These data showed that the Campylobacter-like strains and Wolinella sp. strains FDC 286 and VPI 10279 should be placed in the genus Campylobacter, as there is sufficient genetic distance to warrant a new species, in addition to the DNA-DNA homology data. Strain CCUG 19168, which was identified as $C$. rectus-like, was closely related to the type strain of $C$. rectus. Strain SU C10, which was identified as $C$. curvus on the basis of DNA-DNA homology and phenotypic characteristics (4), differed at $1.4 \%$ of the positions from the type strain of $C$. curvus; this suggests that the species $C$. curvus may be genetically heterogeneous. As indicated previously, Bacteroides gracilis and Bacteroides ureolyticus are genetically misnamed (12). A more extensive discussion of Campylobacter, Arcobacter, Helicobacter, and Wolinella phylogeny based on a 16S rRNA sequence analysis of more than 45 strains will be presented elsewhere.
Description of Campylobacter showae sp. nov. Campylobacter showae (show'ae. L. n. showae, referring to Showa University, where several strains of the species were first isolated). Gram-negative, straight rods. Cells are 0.5 to 0.8 $\mu \mathrm{m}$ wide and 2 to $5 \mu \mathrm{m}$ long with round ends and two to five unipolar flagella. The flagella are unsheathed. Grows in a microaerophilic atmosphere in the presence of fumarate with formate or $\mathrm{H}_{2}$, but prefers to grow under anaerobic conditions. Succinate is produced from fumarate. Oxidase positive. Most strains decompose hydrogen peroxide. Asacchrolytic. Reduces nitrate and nitrite. Arylsulfatase positive. Does not produce lysine or ornithine decarboxylase, alkaline phosphatase, urease, or gamma-glutamyl transferase or hydrolyze hippurate. $\mathrm{H}_{2} \mathrm{~S}$ is produced. Can be differentiated from other Campylobacter species as shown in Table 2. Because of the limited number of reliable biochemical traits which can be used to differentiate closely related Campylobacter species, serologic, DNA probe, or protein profile tests may be required to positively identify isolates of this species. Strains were isolated from human dental plaque and from infected root canals. Pathogenicity is unknown. The $\mathrm{G}+\mathrm{C}$ content of the DNA is 44 to $46 \mathrm{~mol} \%$ as determined by HPLC. The type stain is strain SU A4 (= ATCC 51146). The description of the type strain does not differ from the description of the species.

\section{ACKNOWLEDGMENTS}

This work was supported in part by Public Health Service grants DE-04881 and DE-08303 from the National Institute of Dental Research.

\section{REFERENCES}

1. Badger, S. J., and A. C. R. Tanner. 1981. Serological studies of Bacteroides gracilis, Campylobacter concisus, Wolinella recta, and Eikenella corrodens, all from humans with periodontal disease. Int. J. Syst. Bacteriol. 31:446-451.

2. Christensen, W. B. 1946. Urea decomposition as a means of differentiating Proteus and paracolon cultures from each other 
and from Salmonella and Shigella types. J. Bacteriol. 52:461466.

3. Dokland, T., I. Olsen, G. Farrants, and B. V. Johansen. 1990. Three-dimensional structure of the surface layer of Wolinella recta. Oral Microbiol. Immunol. 5:162-165.

4. Etoh, Y., M. Takahashi, and A. Yamamoto. 1988. Wolinella curva subsp. intermedius subsp. nov.: isolated from human gingival crevice. J. Showa Univ. Dent. Soc. 8:349-354.

5. Hodge, D. S., A. Borczyk, and L.-L. Wat. 1990. Evaluation of the indoxyl acetate hydrolysis test for the differentiation of campylobacters. J. Clin. Microbiol. 28:1482-1483.

6. Laemmli, U. K. 1970 . Cleavage of structural proteins during the assembly of the head of bacteriophage T4. Nature (London) 227:680-685.

7. Lai, C.-H., M. A. Listgarten, A. C. R. Tanner, and S. S. Socransky. 1981. Ultrastructures of Bacteroides gracilis, Campylobacter concisus, Wolinella recta, and Eikenella corrodens, all from humans with periodontal disease. Int. J. Syst. Bacteriol. 31:465-475.

8. Lane, D. J., B. Pace, G. J. Olsen, D. A. Stahl, M. L. Sogin, and N. R. Pace. 1985. Rapid determination of 16 S ribosomal RNA sequences for phylogenetic analyses. Proc. Natl. Acad. Sci. USA 82:6955-6959.

9. Lanyi, B. 1987. Classical and rapid identification methods for medically important bacteria. Methods Microbiol. 19:1-67.

10. Meinkoth, J., and G. Wahl. 1984. Hybridization of nucleic acids immobilized on solid supports. Anal. Biochem. 138:267-284.

11. Pace, B., E. A. Matthews, K. D. Johnson, C. R. Cantor, and N. R. Pace. 1982. Conserved 5S rRNA complement to tRNA is not required for protein synthesis. Proc. Natl. Acad. Sci. USA 79:36-40.

12. Paster, B. J., and F. E. Dewhirst. 1988. Phylogeny of campylobacters, wolinellas, Bacteroides gracilis, and Bacteroides ureolyticus by $16 \mathrm{~S}$ ribosomal ribonucleic acid sequencing. Int. J. Syst. Bacteriol. 38:56-62.

13. Saitou, N., and M. Nei. 1987. The neighbor-joining method: a new method for reconstructing phylogenetic trees. Mol. Biol. Evol. 4:406-425.

14. Smibert, R. M., and L. V. Holdeman. 1976. Clinical isolates of anaerobic gram-negative rods with a formate-fumarate energy metabolism: Bacteroides corrodens, Vibrio succinogenes, and unidentified strains. J. Clin. Microbiol. 3:432-437.

15. Studier, J., and K. Keppler. 1988. A note on the neighborjoining algorithm of Saitou and Nei. Mol. Biol. Evol. 5:729-731.

16. Takamori, K., Y. Etoh, A. Yamamoto, M. Takahashi, F. Mi- zuno, T. Sasaki, and S. Higashi. 1982. Strict anaerobic organisms resembling Wolinella isolated from human gingival crevice. Jpn. J. Oral Biol. 24:541-544.

17. Tamaoka, J., and K. Komagata. 1984. Determination of DNA base composition by reversed-phase high-performance liquid chromatography. FEMS Microbiol. Lett. 25:125-128.

18. Tanner, A. C. R. 1986. Characterization of Wolinella spp., Campylobacter concisus, Bacteroides gracilis, and Eikenella corrodens by polyacrylamide gel electrophoresis. J. Clin. Microbiol. 24:562-565.

19. Tanner, A. C. R., S. J. Badger, C.-H. Lai, M. A. Listgarten, R. A. Visconti, and S. S. Socransky. 1981. Wolinella gen. nov., Wolinella succinogenes (Vibrio succinogenes Wolin et al.) comb. nov., and description of Bacteroides gracilis sp. nov., Wolinella recta sp. nov., Campylobacter concisus sp. nov., and Eikenella corrodens from humans with periodontal disease. Int. J. Syst. Bacteriol. 31:432-445.

20. Tanner, A. C. R., M. A. Listgarten, and J. L. Ebersole. 1984. Wolinella curva sp. nov.: "Vibrio succinogenes" of human origin. Int. J. Syst. Bacteriol. 34:275-282.

21. Tanner, A. C. R., M. A. Listgarten, J. L. Ebersole, and M. N. Strzempko. 1986. Bacteroides forsythus sp. nov., a slow-growing, fusiform Bacteroides sp. from the human oral cavity. Int. J. Syst. Bacteriol. 36:213-221.

22. Tanner, A. C. R., R. A. Visconti, L. V. Holdeman, G. Sundqvist, and S. S. Socransky. 1982. Similarity of Wolinella recta strains isolated from periodontal pockets and root canals. J. Endod. 8:294-300.

23. Tourova, T. P., and A. S. Antonov. 1987. Identification of microorganisms by rapid DNA-DNA hybridization. Methods Microbiol. 19:333-355.

24. Vandamme, P., and J. De Ley. 1991. Proposal for a new family, Campylobacteraceae. Int. J. Syst. Bacteriol. 41:451-455.

25. Vandamme, P., E. Falsen, R. Rossau, B. Hoste, P. Segers, R. Tytgat, and J. De Ley. 1991. Revision of Campylobacter, Helicobacter, and Wolinella taxonomy: emendation of generic descriptions and proposal of Arcobacter gen. nov. Int. J. Syst. Bacteriol. 41:88-103.

26. van Palenstein Helderman, W. H., and K. C. Winkler. 1975. Elective medium for the direct count of vibrio (campylobacter) fusobacteria, bacteroides, selenomonas and veillonella in the gingival crevice flora. J. Periodontal Res. 10:230-241.

27. Wyss, C. 1989. Campylobacter-Wolinella group organisms are the only oral bacteria that form arylsulfatase-active colonies on a synthetic indicator medium. Infect. Immun. 57:1380-1383. 